\title{
Implementation of Faraidh's Provisions In Hibah Wasiat (A Case In Banjar, South Kalimantan)
}

\author{
Wahidah $^{1}$ \& Alias Azhar ${ }^{2}$
}

\begin{abstract}
Implementation of Faraidh's Provisions In Hibab Wasiat (A Case In Banjar, South Kalimantan). This research illustrates the practice of inheritance in the Banjar community of South Kalimantan. The aim is to see the extent to which the provisions of Islamic inheritance law (farāidh) are applied by the member of society in everyday life. This phenomenon is revealed through several field research methods, especially in-depth interviews, the results of which are then analyzed to obtain conclusions. This study found the fact that although in general, the majority of Banjar people of South Kalimantan resolved their inheritance cases by faräidh (Islamic inheritance law), there was a tendency for some citizens to put forward the spirit of "Badamai (Keeping Peace)" to bring up ways of resolving inheritance cases that seemed varied and unique. In such a model, the formulation of the inheritance distribution specified in the faraidh is not fully implemented but is modified through the hibah wasiat (testamentary grant) method. In the case of ashäbah bi al-ghair (heirs of a different gender), the pattern of division of "two to one" is not carried out by the mushi (testator) because of certain reasons/considerations related to the real condition of the heirs (economic level, marital status, age, etc).
\end{abstract}

Keywords: hibah wasiat, Banjar community, inheritance, faräidh.

\begin{abstract}
Abstrak: Implementasi Ketentuan Farāidh dalam Hibah Wasiat (Kasus pada Masyarakat Banjar Kalimantan Selatan). Penelitian ini menggambarkan praktik pembagian waris di masyarakat Banjar Kalimantan Selatan. Tujuannya adalah untuk melihat sejauh mana ketentuan hukum waris Islam (farāidh) diterapkan oleh masyarakat dalam kehidupan sehari-hari. Fenomena ini diungkap melalui beberapa metode penelitian lapangan, terutama depth interview, hasilnya kemudian dianalisis guna memperoleh kesimpulan. Penelitian ini menemukan fakta bahwa meskipun secara umum, masyarakat Banjar Kalimantan Selatan menyelesaikan kasus kewarisan mereka secara faräidh (hukum kewarisan Islam) namun ada kecenderungan sebagian warga yang mengedepankan semangat "badamai" sehingga memunculkan cara-cara penyelesaian kasus kewarisan yang terkesan variatif dan unik. Dalam model pembagian harta warisan semacam itu formulasi pembagian yang telah ditentukan dalam faräidh tidak dilaksanakan sepenuhnya melainkan dimodifikasi melalui metode hibah wasiat. Dalam kasus ashäbah bi al-ghair untuk ahli waris yang berbeda gender, pola pembagian "dua berbanding satu" tidak dilaksanakan oleh mushi (pewaris) karena alasan/pertimbangan tertentu terkait dengan kondisi riil ahli waris (tingkat ekonomi, status pernikahan, usia dan lain-lain).
\end{abstract}

Kata Kunci: hibah wasiat, pembagian waris, masyarakat Banjar, farāidh.

\footnotetext{
${ }^{1}$ Sharia Faculty, UIN Antasari Banjarmasin, Indonesia. Jl. A. Yani No. KM.4, RW.5, Kebun Bunga, Banjarmasin Tim., Banjarmasin, Kalimantan Selatan, 70235

${ }^{2}$ School of Law, North Malaysia University. Persiaran Perdana, Universiti Utara Malaysia, 06010 Sintok, Kedah, Malaysia

E-mail: ${ }^{1}$ wahidah.antasari@gmail.com; ${ }^{2}$ az.alias@uum.edu.my
} 


\section{Introduction}

Recently, there has been a tendency among Muslim community members in several places to settle cases of inheritance distribution through "testamentary wills." Rather than through faräidh (Islamic inheritance law) methods. Such a tendency is revealed in the report of Badan Litbang dan Diklat Puslitbang Kehidupan Keagamaan, Kementerian Agama RI (the Research and Development Agency and the Center for Religious Life Research and Development, Ministry of Religious Affair, Republic of Indonesia) in 2010.

The issue of will/testament and inheritance together discusses the process of transferring property rights of a mushi (testator) or muwarrits (legator) to someone/other parties to whom the will/heir is intended. ${ }^{1}$

The will and inheritance are indeed two main issues which are equally related to the inheritance (tirkah) of someone who has died (heir). Both can only be carried out after the death of the person making the will (mushi) or leaving the inheritance (muwarist). Although the implementation due is similar, both have different legal provisions, portions, and consequences. A will has its portions and provisions, and inheritance has its provisions and portions too. So when there is a practice of a will that has a point of contact with the problem of inheritance, then these two sides of Islamic law may raise a question whether the practice is permitted or not.

Islam with its faräidh provisions is very clear and firm in providing rules relating to the settlement of the will and inheritance. According to Islamic Law, when a person dies, inheritance must be divided according to the faräidh provisions as explained in the Qur'an². In addition, Islam also asserts that inheritance should not be given through a will to children who are automatically heirs. Unfortunately, the community seems to still

${ }^{1}$ The terms like, heirs and heirs, here, are not appropriate to use in such practice or case because both of them have operational definitions which meaning, according to the dictionary, is very different from this designation.

${ }^{2}$ Suhairi Suhairi, 'Perdamaian dalam Pembagian Harta Warisan (Kritik atas Konsep Qatiy dalam Hukum Kewarisan Islam)', Al-Manahij: Jurnal Kajian Hukum Islam, 6.1 (2012), 157-65 (p. 158) <https://doi.org/10.24090/mnh.v6i1.595>. 
not understand the existing provisions, so they then make modification efforts to resolve the problem. Although the Qur'an has explained in detail about the method of distributing inheritance, the community still chooses to use the will and grants method $^{3}$, away from the Islamic inheritance law (faräidh).

The increasing of the practices of inheritance carried out through the grant method indirectly indicate a kind of "dissatisfaction" of the Muslim community regarding the settlement of the distribution of inheritance through faräidh provisions, especially amid gender issues that require equality between men and women. In other words, the discourse of Islamic inheritance began to experience a shift indicated by the emergence of a modified pattern of inheritance settlement cases that are not based on faraidh provisions but the will of the testator.

This phenomenon is interesting to explore intensively and deeply, at least to get an answer whether the practice is in accordance with the principle of justice as desired by Islamic law. Apart from that, this social reality is also a challenge as well as an opportunity for practitioners and observers of Islamic inheritance law to provide a kind of enlightenment through case study in the form of the development of Islamic family law (ahwäl syakhshiyyah).

This article is written based on the author's research that was done in the Banjar community, South Kalimantan. The research is a descriptive study that aims to examine the shifting tendency in Banjar Muslim community of South Kalimantan in solving inheritance problems. The method used is empirical/field research methods, while the data is extracted and collected from a number of informants through depth interviews which are then analyzed using qualitative descriptive analysis. The expected scientific contribution of this research is to encourage local Muslims to apply the correct ways of resolving inheritance cases, in accordance with the guidelines outlined by Allah, the Most Just, and Wise.

${ }^{3}$ M. Nur Kholis Al Amin, 'Hibah Orang Tua Kepada Anak Sebagai Pengganti Waris (Telaah Hermeneutika Terhadap Pasal 211 Kompilasi Hukum Islam)', Al-Ahwal: Jurnal Hukum Keluarga Islam, 6.1 (2016), 29-44 (p. 38). 


\section{Patterns of Distribution of Heritage (Tirkah) among Banjar Communities}

The practice of testamentary inheritance among the Banjar people of South Kalimantan is known as 'amanah 'or' ba'amanah 'or ba'amanat'. The practice is in the form of the appointment of certain people as beneficiaries, including the portion, or it contains a prohibition to divide the inheritance. The will, message, or mandate is generally done verbally, although it is not infrequently done in writing. It stressed that later after the testator died, certain property or rights along with the portion of the distribution should be given to someone referred to in the will. The declaration of the will to the heirs or other beneficiaries is usually witnessed by certain people who are considered close or have the knowledge, such as family relatives, "Tuan Guru (religious master)", or the head of the local RT RW. In many cases, some wills are declared only to "Tuan Guru" or close relatives without the presence of the heirs, but it can also be declared before all heirs. The idea to involve or request consideration from "Tuan Guru." is aimed at preventing the will to come out of the provisions of Islamic law. ${ }^{4}$

Traditionally, the recognition of a will is determined when a family consultation is carried out to settle the inheritance. In this forum, each heir or family member will reveal the existence of the will/message/mandate made by the testator during his lifetime relating to the inheritance. A will/ message will be considered valid if it is approved by at least one witness. If it is only declared by one person, whether he is the person intended in the will, or someone else, then the will/message will be deemed invalid.

The designation of the beneficiary, including the amount of his portion carried out through the will, refers to the precondition that becomes the basis of the will. This is inseparable from the considerations of the deceased heir to the economic condition of his family. On account of this, the types of assets and the portion of the shares received by the heirs may not be the same. A common pattern of distribution usually

\footnotetext{
${ }^{4}$ Research and Development Agency and the Ministry of Religion's Center for Religious Life Research and Development, 'Implementation of Inheritance Law among Indonesian Muslims' (Research and Development of Religious Life Research and Development Agency of the Ministry of Religion, 2010), p. 76.
} 
occurs in the form of designation such as assets in the form of jewelry are given to $\mathrm{A}$, assets in the form of a house/ shop for $\mathrm{B}$, while land/ estate is given to $\mathrm{C}$, and so on following the wishes of the parents. ${ }^{5}$ The ways or models of wills practiced by the Banjar people of South Kalimantan are similar to the practice of grants formatted through a will. ${ }^{6}$ The main objective is to avoid disputes or "barabut" (seizure of inheritance) among heirs or other beneficiaries.

Because it is considered legal, and, at the same time, all the heirs agree, the practice of grants through this will is increasingly being practiced by the community and so far it has never caused any conflict among the heirs. There are two underlying reasons why such conflicts rarely occur. The first: because of the high obedience and respect of the heirs to their parents (heirs), and, the second: the belief that neglecting the message/mandate of parents will bring bad consequences:

1. The heir (deceased) becomes disturbed or uneasy in his grave.

2. The heir will become uneasy or get no blessing in his life, and will always feel visited by his deceased parents through dreams. ${ }^{7}$

To give an illustration of the practice of distributing inheritance through the will/or testament scheme, the following description will present three concrete examples of cases as happened in the Banjar community in South Kalimantan. ${ }^{8}$

The Hulu Sungai Selatan case. Br, whose address is in the village of Hamalau, District of Sei Raya Kandangan, died in 2013 at the age of

${ }^{5}$ Wahidah at all, 'Grant Calculated as Part of Inheritance (Case Study in Barito Kuala and Banjarmasin)' (Research Report, Research, and Publishing Center of the Antasari State Islamic Institute of Banjarmasin, 2013).

${ }^{6}$ See the conclusion of the research, in which method of the grant was done under the granter's determination that, after the occurrence, there was no settlement of inheritance distribution as the gift at the same time becomes inheritance.

7 According to belief, the existence of such disputes will result in the heir (deceased) is not peaceful in the grave. See Report from Research and Development Agency and the Ministry of Religion's Center for Religious Life Research and Development, p. 78.

${ }^{8}$ All cases regarding the Practices of Inheritance Settlement in Banjar Communities can be accessed in full, through $\mathrm{Hj}$ Wahidah $\mathrm{Hj}$. Wahidah and $\mathrm{Hj}$. Faridah, Praktik Penyelesaian Harta Warisan Pada Masyarakat Banjar (Antasari Press Banjarmasin, 2018) <http://idr.uin-antasari. ac.id/11741/>. 
85 years. He left his wife and seven children, three of whom are women. The legacy is only in the form of vacant land. During his lifetime, Br. wishes to grant one-third of the land area to his four children having no permanent jobs. Whereas two of his sons who are civil servants and one of their daughters who is considered to be rich did not receive this part of the grant. The remaining land, which covers an area of about two-thirds, is used as an inheritance after part of it had been set aside/ prepared for organizing corpses, burials until the "menyaratus" ceremony (100 days commemoration).

The desire to give special grants to his four children had been expressed by Br. to his wife when he was still alive. ' By his wife, then, this kind will "was conveyed to/in front of all their children as heirs. All the sons of Br. of these seven agreed to carry out their father's will. So even though the three children of seven siblings got a smaller share of the inheritance, they felt no objections whatsoever, even they were happy".

Furthermore, one-third of the land granted by Br. to the four children was divided into four which was not exactly the same as each other because the location of the land was not located in a single entity even though they were close together. ${ }^{10}$ The remaining two-thirds of the land, after being deducted to cover the costs of death affairs, was then sold by the heirs and the proceeds of the sale are divided in a faraidh manner. Then, all the money they received from the sale of this land was given to their mother (the wife of the late $\mathrm{Br}$ ). ${ }^{11}$

The Tabalong case. Ast. bin Jln, passed away on November 12, 2009, leaving his wife namely St. Rph. binti Slmn and five children (four boys and one girl). ${ }^{12}$ During his life, Ast owned several plots of land, one of which, located at the Padat Karya village, and a house located in the village of Sulingan. Before Ast. died, he had made a will to his children with the intention that after his death his inheritance would be divided

${ }^{9}$ Delivered a year before his death.

${ }^{10}$ Until now there has been no attempt by the heirs to certify the gifted land.

${ }^{11}$ Interview with Nr., an alumnus of the Islamic faculty of IAIN Antasari Banjarmasin, on 18 and 19 August 2018) at his residence in the village of Hamalau, together with My. (wife of Nr), Uw., Krd, (uncles) Is., Hnd, Mrd. Frd., (aunts), Uyn, Hny., Mrgt, and Iyl (cousins).

${ }^{12}$ They are Mhr., Rjl., Rsd., Krd., Zh. 
equally to all of his children regardless of gender differences. The will was made in writing. After Ast died, the message was then carried out by his children so that the property mentioned earlier was shared equally between boys and girls. All heirs agreed and no one objected.

Two years after the death of Ast bin Jln, his wife, St. Rph. binti Slmn passed away on 6 December. At the time of their mother's death, no will was made, except money and gold. ${ }^{13}$ The inheritance is then shared by the heirs in a faräidh manner following the pattern of to-one division (two-part for boys and one part for girls). Such a pattern of distribution was agreed upon by all heirs without anyone questioning it.

Apart from the inheritance which has been inherited, there is still another inheritance in the form of productive rice fields plus a house. The heirs agreed that the land in the form of rice fields was not be divided and left to produce. If after harvesting, the results will be distributed to all heirs. While the property in the form of their next house is rented and the money from the rent is used for the "arwahan ritual" of their parents. ${ }^{14}$

The Hulu Sungai Tengah case, Eff. is one of the heirs of Slm. who died on December 26, 2004. Slm left four children, namely Rsd., Rst. Rsa., and Eff. These three daughters were graduated from economics, while Eff. was a bachelor of Education. The assets left were two hectares of land in the Pagat area, and $6.100 \mathrm{~m} 2$ of paddy land located in the village of Banua Budi. All the land had been divided by Slm. to all of his children when he was still alive. Distribution was carried out five years before his death, only with a "batunjuk (designation)" method without a written document. In the division, Slm., brought together all of his children, then he gave those who had already worked "less" parts than those who had not a permanent job. Slm. gave his children the wealth in such a way to prevent from conflicts for inheritance. None of the heirs was concerned about the portion of the property they receive

${ }^{13}$ The informant was reluctant to mention the amount of money and gold from the mother.

${ }^{14}$ Interview by phone with Zh (youngest child), and Mhr. (the eldest) of the St. Rph., and Ast., On 31 August, and 1, 2 September 2018, along with other heirs, namely the daughters of the heir and daughter-in-law. 
even though the value varies. ${ }^{15}$ Five years later, Slm died and did not leave any assets to the extent that the costs for handling the funeral were handled by the village community through the contribution fund.

\section{Case Analysis from the Perspective of Islamic Law}

Grants, wills, and inheritance are essentially three different issues from one another. ${ }^{16}$ Although they are within the scope of the transfer of rights and property of one person to another person, the legal consequences of the three systems are different.

Hibah (grant) is the transfer of assets made by the owner of the property when he/she is still alive. While wasiat (testament) is a transfer of assets carried out by the owner to another party, in oral or written form, but it will take effect only after the testator dies. Meanwhile, Pewarisan (inheritance) is a legacy from a party to another party after his/her death under blood relations or marriage ties.

Hibah and wasiat are legal deeds. But when they are carried out without regard to the rules or contrary to the rules of inheritance law, they have the potential to deviate from the existing provisions and consequently may not be permitted. After all, if every family carries out such legal actions, practically the provision of inheritance will no longer have effects and the people who are supposed to get it through the testamentary mechanism, such as the poor relatives who are mamnīl mahrūm (forbidden), or heirs who are hijāb hirmān (obstructed). ${ }^{17}$

The increasing number of inheritance settlement cases through in the hibah wasiat (testamentary grant) mechanism indicates that the public seems to no longer heed Islamic inheritance rules and legal signs that

${ }^{15}$ Interview with Effs on 7-9 September 2018 at Sari gading street, Banua Budi Village, Barabai District.

${ }^{16}$ See also Paula Franciska, 'Wasiat Kepada Ahli Waris Menurut Kompilasi Hukum Islam dan Kitab Undang-Undang Hukum Perdata', NotariuS, 11.1 (2018), 115-29 (p. 116) <https:// doi.org/10.14710/nts.v11i1.23129>.

${ }^{17}$ Mamnī '(Mahrüm) and Mahjub are two terms used to refer to heirs who are equally not entitled or cannot receive an inheritance because of reasons preventing it. Mamnū was hindered by nature: slaves, murderers, and different religions, including apostasy. While mahjū $b$ hindered because some people or heirs are closer relations, degrees, and the strength of kinship to the heir. 
explain how the will should be carried out. The diverse practices of the community, therefore, have to be explored in-depth to determine whether or not the case is in accordance with provisions of fiqh (Islamic law). Essentially, the limitation of a will is intended to prevent any of the heirs from feeling aggrieved because the amount of assets given through the will exceeds the maximum limit (one third). The maximum limit, however, can be exceeded only if all of the heirs agree.

Furthermore, the practices of hibah wasiat, seen from the Islamic legal perspective may result in two kinds of legal status. According to a line of thought, such practices are not following the provisions of Islamic law. While another perspective views the practice still in accordance with the principles of Islamic law because of several justification reasons.

For supporters of the first line of thought, Allah, in Surah an-Nisa ' 11 , and 12, has established detailed faräidh laws concerning the furüdhul muqaddarah (the determined portion) and the rights of the heirs of ashābul furūdh (the portion holders). The two verses serve both as a legal basis and as guidelines to settle the issues of inheritance. Besides, at the end of the two verses, Allah Says:

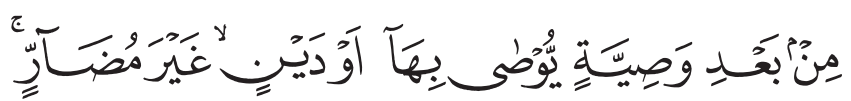

Asserting that the settlement of the inheritance was carried out after the fulfillment of the testator's will. Therefore, the will is not included in the format of inheritance as its implementation must take precedence over the distribution of inheritance. In addition, the above provision is also backed up by the Prophet's hadith saying "Lā washiyata li wāritsin (no wills for the heirs)" and a hadith saying: Iqsamu al-māla baina ablil farāidhi 'ala kitäbillah (Divide your wealth among the heirs following the book of Allah)".

As for the matter of the heir's consideration of "justice" when distributing property to the children, the proponents of this group view that this matter cannot be handed over to humans, whomever the person is, and whatever the method or rules of distribution. Because whatever human effort to realize justice they will not be able to carry out the fair distribution as perfect as determined by God. This is as stated at the end of the word of God in the 
Surah an-Nisa' verse 11 which means: "Your parents and your children, you do not know which of them is closer (much) to your benefit" ${ }^{18}$ According to Ali Ash-Shābuni, the fragment of this verse firmly signals that Allah, the Wisest. is the one who is competent and has the right to regulate ways of settling the distribution of inheritance. Humans will not know which of the parents and children are closer or greater benefits to someone. Only Allah, the Most Holy, the All-Wise, the All-knowing, can determine the true form of justice. The provisions set by God, therefore, must contain an element of justice, because no individual can make rules and laws better, juster, and more relevant to humanity than God. ${ }^{19}$

The Qur'an and the Hadith, the main sources of Islamic law, come from the Most Just, the Truest, and the All-Knowing of everything to provide the best solution for human beings. Furthermore, the Qur'an hints that the enforcement of "justice" is part of the principle of establishing law in Islam. As a provision that comes from God, the Most Just, the Truest, and the All-Knowing of the benefit of His servants, God's law (Shari'a) must contain perfect justice. The Muslim, therefore, according to this first school, must carry out faraidh provisions in resolving inheritance. ${ }^{20}$ On account of this view, the pattern of inheritance distribution through means of a grant or a will as practiced by the many Muslim communities can not be justified and the compromise regarding differences of opinion in this context seems to be experiencing a "dead end". This happens when one party evaluates the inheritance verses as qathizy verses, so there is no way to do ijtihäd on them. The same is true with the case relating to parental obligations. ${ }^{21}$

In contrast to the rule of law which is strictly held by the first school of thought above, the second stream sees that the law is created to achieve justice and benefit for humans. There is no theoretical argument whatsoever that can deny the dynamics or changes in the application of Islamic law.

${ }^{18}$ In addition, there are still a few verses in the Qur'an that hint about this principle of justice, such as QS. al-Nahl verse (90) and al Hujurat verse (9).

${ }_{19}$ Muhamad Ali Al Shabuny, Al-Mawārits Fì al-Syariat al-Islāmiyyah Fi Dhaui al-Kitab Wa al-Sunnah, (Jakarta: (Dar al-Kutub al-Islamiyyah, 2010), p. 22.

${ }^{20}$ Ro'fah Setyowati Rahmawati, 'TeNggat Waktu Pembagian Harta Warisan dalam Perspektif Hukum Islam', Diponegoro Law Journal, 5.3 (2016), 1-19 (p. 3).

${ }^{21}$ Al Qur'an, surat al Baqarah, verse: 180. 
Islamic inheritance law (farāidh), with its nature, will not experience conflict in the face of changing times. ${ }^{22}$ The proponents of this thought define "justice" as "giving someone what they are entitled". They assert that receiving an inheritance is a right, and obtaining shares in accordance with faraidh provisions is also a right. Both must be fulfilled in each process. This principle is clearly and firmly correlated with the problem of Islamic inheritance (farāidh) which states that: For boys, there is a nashīb (right) and for daughter, there is also a nashib (right) of the inheritance of both parents. They both have nashïban mafrudhā (the absolute right). Nonetheless, according to this perspective, the existence of the same rights by heirs of a different gender does not necessarily mean the same portion or the same quantity.

Islamic law, with its principle of stipulation based on equality and justice, indeed, has established the rules of faräidh in detail. ${ }^{23}$ However, concerning the principles and methods of determining Islamic law, the Qur'an always pays attention to human capabilities, by giving concessions to implement these laws according to their abilities. Thus, humans will not be burdened outside their limits. Allah SWT. as Musyarri (Law Maker) has set several rules (law) for humans in the form of taklif (giving burden) which is easy to implement and hassle-free. This principle is related to the term 'adam al-haraj (eliminating difficulties). While takliff (burden) is God's demand to act and to stay away from everything God forbids that is considered obedient. However, this command of Allah does not mean abolishing His rules altogether. The principle of fiqh المشقّة تجلب التيسير "difficulties bring convenience", is a form of juridical assertiveness related to some rukhshah (relief) that Allah and the Apostle set. Umar bin Khattab himself was often seen as a friend whose thoughts were "controversial" or even different from what was once practiced in the time of the Prophet.

${ }^{22}$ Modernization in this field can only be done as long as it is appropriate, or at least not in conflict with the basic principles of Islam. For example, in the aqad (transaction) problem. There are no official rules that must be followed to assess the validity of a transaction, but, as the Qur'anic sign, sufficient with the willingness of both parties to the transaction. The very rules contain basic principles that provide space for Islamic law to adapt to the times. So that Islamic law is not rigid, in accordance with its flexible and dynamic character.

${ }^{23}$ Maimun, 'Pembagian Hak Waris Terhadap Ahli Waris Beda Agama Melalui Wasiat Wajibah dalam Perspektif Hukum Kewarisan Islam', ASAS, 9.1 (2017), p. 1 <https://doi. org/10.24042/asas.v9i1.1209>. 
However, because of "his brilliant ideas," Umar's opinion later became one of the sources of law that could be held. Umar's wisdom in some instances of inheritance, for example, is aimed at upholding justice and providing benefits to the community. One important conclusion from several Umar's ijtihad is his contextual understanding of the law. He was not rigid in understanding the legal texts literally and partially, because Umar was more concerned with the spirit of the text as a whole. ${ }^{24}$

The principle of maslahat ${ }^{25}$ which is embraced by Islamic law allows the appearance of differences because of different maslahat. As urf (tradition) of every nation varies then it is natural if there are variations in opinions regarding their understanding of inheritance verses with an emphasis on the concept "li al-dzakari mitslu hazh al-untsayain (for boys twice the portion of girls)." Understanding this law at all times is needed, especially in the current era of globalization and information. The attitude of some people who consider only one legal flow is true and applies in all places and at all times is very unfavorable to Muslims who believe that Islamic law remains relevant throughout time and place (Sälih li kulli zamān wa makān). It is not difficult for reason to understand that the starting point for implementing the provisions of Allah relating to the taklif is solely for the benefit of the whole human race. Herein lies the perfection, flexibility, generality, order, and dynamism of Islamic law.

Furthermore, legal change and social change are phenomena that affect each other. Changes in the law in a country can affect social change in society. Likewise, social change in society can lead to changes in law in a country. ${ }^{26}$ Regarding changes in this law, Ibn al Qayyim al-Jauziyah in

${ }^{24}$ The examples are many, including Umar's ijtihad related to inheritance issues. The Umrayatain Case (Gharawain, Gharibatain), The Umariyah Case (Musyerdah, Himariyah, Hajariyah, Yammiyah), The Aul and The Dzawi al-Arham Inheritance Case.

${ }_{25}$ Simply, maslahat comes from the word al sulh or al islah which means peace and tranquility. Peace is physically oriented, whereas harmony is psychic oriented. Maslahat can be interpreted by taking advantage (bring goodness) and reject the harms. This principle plays an important role, even according to experts in Islamic law such as al-Syathibi, it is seen as the ultimate goal of legal reconciliation. If a benefit is said to be a legal principle, then the law must provide value (goodness) to the user of the law itself.

${ }^{26}$ Syamsul Bahri Salihima, Perkembangan Pemikiran Pembagian Warisan Dalam Hukum Islam Dan Implementasinya Pada Pengadilan Agama (Jakarta: Prenadamedia Group, 2015), pp. 17-18. 
his book, states, that "Changes and differences in fatwas are in accordance with changing times, places, conditions, intentions, and customs". ${ }^{27} \mathrm{He}$ also reinforced his theory by pointing out that so many fatwas issued by Shahabah (prophet's companions) and thabiin (later generation) ${ }^{28}$ as well as muftis, ${ }^{29}$ were related to changes in the law. The existence of these various edicts has led to different laws on the same issue. This is caused by the diversity (difference) of science, situation, conditions, place, and or time. The concrete examples of legal changes in Indonesia can be found in the Compilation of Islamic Law in book II in which various breakthroughs have emerged through the provisions in certain articles.

Ijtihäd is known as one of the sources of Islamic law. Despite its dzanny in nature, it is still needed in the situation the two main legal sources, the Qur'an and the Hadith, say nothing about a case. So, it is a mistake to say that the door of ijtihad has been closed because the mindset and way of thinking of humans are constantly changing. Ijtihad will always open and remain dynamic following the development of human thought and the dynamics of Islamic law itself. ${ }^{30}$ Concerning inheritance issues, Islam does not distinguish the size of the heirs or the amount of inheritance. All heirs have the same rights to receive a portion of the assets left by their parents. As for differences in rights/parts received, it cannot be used as a standard to declare inequality/injustice of faräidh. ${ }^{31}$

The practice of grants that resembles a will and/or inheritance carried

${ }^{27}$ Muhammad Ibn Abi Bakar Ayyub Zar'i Abu Abdillah, I'lām al Muwaqqiìn an Rabb al-Alamin (Beirut: Dar al jabal, 1973), p. 28.

${ }^{28}$ Among the prophet's companions are Umar bin Khathab, Ali ibn Abi Talib, Ayesha, Abu Zaid al Hudri, Ibn Abbas, Ibn Umar. Whereas from the thabi'in: Said Ibn Musayyab, Urwah bin Zubair.

${ }^{29}$ Among the Muftis, the fatwa experts scattered in various regions, such as Madinah, Kufa, Syam Syiria), Basrah, Egypt, Yemen, or those from Baghdad

${ }^{30}$ It is natural that later emerging concrete cases are contemporary in nature and require a legal answer. In connection with the problem of inheritance, many examples of the settlement of inheritance cases have emerged through the thought of famous mujtahids. This is following the opinion of Jad Ahmad Mubarak., Banjar Ulama as well as the author of the book Is'af al Raghibin fi 'Ilmi al Faraidh. See also Research and Development Agency and the Ministry of Religion's Center for Religious Life Research and Development, pp. 82-84.

${ }^{31}$ Wahidah, 'Relasi Setara Antara Laki-Laki dan Perempuan dalam Kasus Kewarisan Islam (Faraidh), Syariah: Jurnal Hukum dan Pemikiran' <Https://Jurnal.Uin-Antasari.Ac.Id/Index.Php/ Syariah/Article/View/2144>. 
out by the Banjar community is a unique mechanism of the transfer of one's rights and property to another person. As in this case, the "will" is generally done verbally to the heirs in a family consultation. The type of goods or property to be given is also determined by parents as they wish and as they consider it "fair and just". Grants to children, indeed, should be given fairly, and do not vary in value. But the measurement of justice does not necessarily mean to be the same. Parents as owners of the property have right whatever they want to determine what to give to their children. Under such a situation, the practice of division is not always the same. It may be the same between boys and daughters, but it may also be different as it is carried out according to the economic condition of the heirs and considerations of "justice" in the parents' minds.

The Banjar Muslim community, as seen in the case above, considers that the pattern of inheritance distribution through "hibah wasiat" mechanism will bring maslahat (benefits) to all family members, ${ }^{32}$ Upon his/her death, the owner of the property does not want his wealth to become something that triggers hostility, fights, or breaking the ties of friendship among the family members. Thus, it is clear that the maslahat principle has become the main reason why the practice of hibah wasiat is carried out.

There are several interesting facts that deserve attention regarding the three cases forwarded earlier. In the case of the Hulu Sungai Selatan (HSS) district, for example, the type of settlement model involving the ishläh process is procedurally in accordance with the provisions of article $183 \mathrm{KHI}$. This is proven by the fact that there is no objection from the heirs even though some of them did not receive anything as a grant from their parents. Likewise, the heir's agreement to give all part of their inheritance to the surviving mother (wife of the heir). ${ }^{33}$

The same is true with the Tabalong case where Ast, in his will, determined the inheritance rights of his children by the pattern of "equal"

${ }^{32}$ This is in accordance with the opinion of Jad Ahmad Mubarak., An Ulama of Banjar as well as the author of Risalah Is'af al-Raghibin fi Ilmi al-Faraidh. See also the Ministry of Religion Report, 'Penerapan Hukum Waris di Kalimantan Selatan', pp. 82-84.

${ }^{33}$ This is because the statement was made during a family gathering attended by all heirs, including three other children. 
division. Although there is a hadith forbidding testamentary on heirs ("la washiyata li wäritsin") because the will of the testator was addressed to all of his children in ways that there was no objection from the heirs, the wills, therefore, can be justified. Thus, the agreement and sincerity of the heirs to carry out the will become the reason for the justification of the will practices; all the more, the legacy was also carried out following farāidh's guidance. ${ }^{34}$

The inheritance cases that occur in Tabalong belongs to al munasakhah because the first heir also becomes the second heir. As the distance between the death of the first heir and the second heir was not too far (about two years only), it is natural if the distribution of inheritance was done after the death of the second heir. ${ }^{35}$ As for the settlement mechanism of a part of jointly managed assets in the form of the productive land from which the results are then distributed to all existing heirs. Such a mechanism is justifiable as it follows the provisions of Islamic law especially Islamic Law Compilation (KHI) article 189 which states:

(1) If the inheritance to be divided is in the form of agricultural land with an area of fewer than 2 hectares, the unit shall be maintained as before, and utilized for the joint benefit of the heirs concerned.

(2) If the aforementioned provision is not possible because among the heirs concerned there who need money, then the land can be owned by one or more heirs who by paying the price to the rightful heirs in accordance with their respective sections.

Similarly, the case in the Hulu Sungai Selatan district, where all heirs agree and are willing to give their rights and part of their inheritance to the surviving mother (wife of the heir), such settlement model using the ishlāh process is procedurally following the provisions of article $183 \mathrm{KHI}$.

As for a part of the inheritance that is not divided up to heirs to cover expenses of "bahaul" or "haulan" (yearly commemoration), such cases is also justifiable as long as all the heirs agree to do so. Usually,

${ }^{34}$ Statement of the Prophet Muhammad. regarding justice in giving grants to all children, and the permission to withdraw the object of the grant as an exception.

${ }_{35}$ The two inheritance objects are also from the joint property of the Ast couple. and St. Rph. 
in cases like this, heirs are reluctant to express their wishes for the property distribution. In the case of Tabalong, the rented houses were used as a treasure "baulan" as according to the heirs, they have received a lot from their parents' legacy. Therefore, As long as the house still be rented out, and none of the heirs who want it to be distributed, then the function of the house will continue to run as what they have agreed from the beginning. The heirs are open if there is among their brothers who ask that the inheritance be distributed. But to date, none of them have expressed it.

Concerning the case of the Hulu Sungai Tengah regency (HST), because the process of transferring property rights was carried out while the owner of the property was still alive, then this case is categorized as hibah (grant) rather than inheritance.

The practice of distributing inheritance which is carried out following the will of the testator as happened in the Banjar community in South Kalimantan shows a transition of preference from faraidh law to will, or at least an attempt to modify the law that mediates faraidl law with the will of under the name "hibah wasiat/Probate Grant". The term "probate" here, is meant by legal actions that resemble the act of a grant, but are not concretely done as a grant law. ${ }^{36}$ The concrete form is the heir, while his life, took the initiative to determine the portion of the rights/property owned to each of his children after he dies. The determination is carried out in the form of the person A gets this, and the $\mathrm{B}$ gets it, and so on, based on the consideration and sense of justice of the will-maker. The sense of justice according to the parents here is indeed not a definite measure and is usually expressed in the form of a saying: "Later, if your father dies, your part is something such and such, don't be jealous or hate your other siblings". In this way the heir hopes that what he said at that time could be realized by his children when he died, preventing the emergence of disputes among heirs because it was predetermined. This purpose seems to be used as a justification for applying the practice of testament in solving tirkah problems.

${ }^{36}$ The definition of "testamentary gift" here is similar to the operational definition in the title of the research "testamentary distribution of inheritance before the testator dies. 


\section{Conclusion}

Based on the analysis of the cases above, it can be concluded that although in general, the Banjar people of South Kalimantan are still resolving their inheritance cases in farāidh (Islamic inheritance law), but there is a tendency of some citizens to prioritize the spirit of "badamai" to find ways of solving inheritance cases that seem varied and unique. In such inheritance distribution models, the formulation of the divisions specified in the faräidh, including the distribution pattern of "two to one" for heirs of different gender, is not fully implemented but is modified through the will testamentary method. Thus in the case of ashābah bi al-ghair (joint heirs) for heirs of different gender, the pattern of division of "two to one" is not carried out by the mushi (testator) for certain reasons based on the real condition of the heirs (economic level, status marriage, age, and others).

\section{Bibliography}

Amin, M. Nur Kholis Al, 'Hibah Orang Tua Kepada Anak Sebagai Pengganti Waris (Telaah Hermeneutika Terhadap Pasal 211 Kompilasi Hukum Islam)', Al-Ahwal: Jurnal Hukum Keluarga Islam, 6.1 (2016), 29-44.

Franciska, Paula, 'Wasiat Kepada Ahli Waris Menurut Kompilasi Hukum Islam dan Kitab Undang-Undang Hukum Perdata', NOTARIUS, 11.1 (2018), 115-29 <https://doi.org/10.14710/nts.v11i1.23129>.

$\mathrm{Hj}$. Wahidah, $\mathrm{Hj}$ Wahidah, and Hj. Faridah, Praktik Penyelesaian Harta Warisan Pada Masyarakat Banjar (Antasari Press Banjarmasin, 2018) $<$ http://idr.uin-antasari.ac.id/11741/>.

Interview by phone with $\mathrm{Zh}$ (youngest child), and Mhr. (the eldest) of the St. Rph., and Ast., On 31 August, and 1,2 September 2018, along with other heirs, namely the daughters of the heir and daughter-in-law.

Interview with Eff's on 7-9 September 2018 at Sari gading street, Banua Budi Village, Barabai District.

Interview with Nr., an alumnus of the Islamic faculty of IAIN Antasari Banjarmasin, on 18 and 19 August 2018) at his residence in the village of Hamalau, together with My. (wife of $\mathrm{Nr}$ ), Uw., Krd, 
(uncles) Is., Hnd, Mrd. Frd., (aunts), Uyn, Hny., Mrgt, and Iyl (cousins).

Maimun, 'Pembagian Hak Waris Terhadap Ahli Waris Beda Agama Melalui Wasiat Wajibah Dalam Perspektif Hukum Kewarisan Islam', ASAS, 9.1 (2017) <https://doi.org/10.24042/asas.v9i1.1209>.

Ministry of Religion Report, 'Penerapan Hukum Waris di Kalimantan Selatan'.

Muhammad Ibn Abi Bakar Ayyub Zar'i Abu Abdillah, I'lam al Muwaqqiin an Rabb al Alamin, Beirut: Dar al-Jabal, 1973.

Rahmawati, Ro'fah Setyowati, 'Tenggat Waktu Pembagian Harta Warisan Dalam Perspektif Hukum Islam', Diponegoro Law Journal, 5.3 (2016), 1-19.

Research and Development Agency and the Ministry of Religion's Center for Religious Life Research and Development, 'Implementation of Inheritance Law among Indonesian Muslims' (Research and Development of Religious Life Research and Development Agency of the Ministry of Religion, 2010).

Shabuny, Muhamad Ali Al, Al-Mawarits Fi al-Syariat al-Islamiyyah Fi Dhani al-Kitab Wa al-Sunnah, Jakarta: Dar al Kutub al Islamiyyah, 2010.

Suhairi, Suhairi, 'Perdamaian dalam Pembagian Harta Warisan (Kritik atas Konsep Qat'iy dalam Hukum Kewarisan Islam)', Al-Manahij: Jurnal Kajian Hukum Islam, 6.1 (2012), 157-65 <https://doi.org/10.24090/ mnh.v6i1.595>.

Syamsul bahri Salihima, Perkembangan Pemikiran Pembagian Warisan Dalam Hukum Islam Dan Implementasinya Pada Pengadilan Agama, Jakarta: Prenadamedia Group, 2015.

Wahidah, 'Relasi Setara Antara Laki-Laki dan Perempuan dalam Kasus Kewarisan Islam (Faraidh) Syariah: Jurnal Hukum dan Pemikiran' <https://jurnal.uin-antasari.ac.id/index.php/syariah/article/view/2144>.

Wahidah at all, 'Grant Calculated as Part of Inheritance (Case Study in Barito Kuala and Banjarmasin)' (Research Report, Research, and Publishing Center of the Antasari State Islamic Institute of Banjarmasin, 2013). 